\title{
Political Parties in Indonesia and the Internet: A Comparative Analysis
}

\author{
Ella S. Prihatini ${ }^{1}$ \\ Department of Political Science and International Relations, School of Social \\ Science ${ }^{1}$ \\ University of Western Australia, Perth, Australia ${ }^{1}$ \\ ella.prihatini@research.uwa.edu.au ${ }^{1}$ \\ Muhammad Sigit Andhi Rahman² \\ International Relations Study Program, Faculty of Humanities ${ }^{2}$ \\ President University, Kota Jababeka, Indonesia ${ }^{2}$ \\ andhi.rahman@president.ac.id²
}

\begin{abstract}
ABSTRAK
Makalah ini adalah kajian pertama tentang penggunaan internet oleh partai-partai politik di Indonesia. Lebih lanjut, makalah ini juga mendokumentasikan indeks kinerja situs web partai dan popularitas secara online dalam kampanye pada tahun 2019. Tujuan dari studi perbandingan ini adalah untuk melihat bagaimana internet digunakan oleh partai-partai politik Indonesia menjelang pemilu 2019. Kampanye internet terdiri dari dua bagian: kehadiran online melalui situs partai politik, dan pemasaran politik melalui media sosial. Total 16 partai yang berpartisipasi dalam pemilihan 2019 diteliti untuk mengetahui bagaimana mereka menggunakan situs web resmi dan platform media sosial. Kami membuat indeks berdasarkan daftar fitur situs web (sistem penilaian) dan kemudian mengklasifikasikannya menjadi 4 variabel (penyediaan informasi, mobilisasi, keterlibatan, dan kecanggihan teknologi) yang keseluruhannya berisi 43 fitur. Kami juga memvisualisasikan analisis statistik deskriptif pada akun media sosial partai-partai tersebut menggunakan perangkat lunak RStudio. Studi ini menemukan bahwa meskipun setengah dari populasi nasional Indonesia telah aktif menggunakan internet, partai-partai politik belum mencapai potensi maksimal mereka dalam menggunakan media digital untuk menyebarkan pesan-pesan politik dan propaganda. Kualitas sebagian besar situs web masih di bawah standar. Selain itu, kualitas situs web tampaknya tidak memiliki hubungan dengan sumber daya keuangan dan ukuran parlementer partai politik saat ini. Rata-rata, akun media sosial resmi yang dijalankan oleh pihak hanya digunakan dalam 3,25 tahun terakhir. Partai-partai tua yang mapan di Indonesia terus terlibat
\end{abstract}


dengan konstituen mereka tanpa banyak bergantung pada media sosial. Namun, situasi ini sangat mungkin berubah di masa depan karena elit partai sekarang mulai melihat ke platform ini ketika mereka mencari dukungan dari pemilih milenial.

Kata kunci: Indonesia, Media sosial, Pemilihan Umum, Partai Politik, Situs web Partai Politik, Internet, Analisis Konten

\begin{abstract}
This is the first such study of the use of Internet by political parties in Indonesia. It also documents parties' websites performance index and online popularity for campaigning in 2019. The purpose of this comparative study is to look at how the Internet was used by Indonesian political parties in the lead up to the 2019 elections. Internet campaign consists of two parts: online presence through political party website, and political marketing through social media. 16 parties participating in the elections next year were examined for how they are utilizing official websites and social media platforms. We created an index based on list of website features (scoring system) and then classify it into 4 variables (information provision, mobilization, engagement, and technological sophistication) containing 43 features. We also visualise the descriptive statistical analysis on parties' social media accounts using RStudio software. The study found that despite half of Indonesian national population is using the Internet; political parties were not yet achieving their maximum potential in using the digital media to disseminate political messages and propaganda. The quality of most of the websites have been subpar. In addition, the quality seems to have no relationship with the financial resources and the current parliamentary size of political parties. On average, official social media accounts run by political parties has only been used in the last 3.25 years. Well-established older parties in Indonesia continue to engage with their constituents without heavily relying on social media. Yet, this situation is very likely to change in the future as parties' elites are now beginning to look into this platform as they seek out to the millennials for electoral support.
\end{abstract}

Keywords: Indonesia, Social media, Elections, Political parties, Political party websites, Internet, Content analysis 


\section{Introduction}

The Internet has become an important part of contemporary democracy, as it offers a tool for political communication which connects ordinary people to the powerful and influential. Social networking sites are also playing a crucial role in developing a more direct relationship between politicians and citizens in a networked (Enli \& Moe 2017; Gainous \& Wagner 2013b). Unlike conventional media, such as print media and television, social media connects people with no concern for distance and the communications can be immediate. "The feedback and the discovery of some information and its distribution can travel at speeds never before seen (Gainous \& Wagner 2013a, p. 10)."

Despite a growing number of studies on the impact of the internet on politics, most are based on the Western societies. Only a few examine Indonesia as a case study and even less on whether political parties are engaging the Web and social media platforms in order to maximize their virtual campaigning. In order to address these shortcomings, we analyze and compare 16 political parties during the 2019 general election campaigns. Our comparative study is looking at parties' cyber campaign which consists of two parts: online presence through parties' website and political marketing through social media.

Drawing upon previous research on campaigning websites in Asia (Gadekar et al. 2011; Naseer \& Mahmood 2016) and the utilization of social media by Indonesian political parties and politicians (Johansson 2016a; Johansson 2016b; Beers 2014; Alami 2013), this study contributes to the discussion in two ways. Firstly, it shows that Indonesian parties were not yet achieving their maximum potential in using the digital media to disseminate political messages and propaganda. Well-established older parties in Indonesia continue to engage with their constituents without heavily relying on social media. The study lends support to Merlyna Lim's (2013a) claim as social media activism in Indonesia has not been translated into online political activism. The fact that parties' Twitter and Instagram accounts, for example, only being followed by a fracture of millions of active users indicates most Indonesians are not channeling their political aspirations on the internet.

Secondly, by modifying Gibson \& Ward (2002) and Lilleker et al. (2011) works, we have created the ranking system for Indonesian parties websites. The ranking is based on websites' performance on four aspects, namely (1) information provision, (2) mobilization, (3) engagement, and (4) technological sophistication. We also visualized parties' online popularity on four social media platforms: Facebook, Twitter, Instagram, and YouTube. The graphs suggest that parties' parliamentary size only has a strong and positive correlation $(0.67)$ with the number of years party has 
been on Facebook. On the other hand, this study finds older parties are less popular on Facebook and YouTube compared to the younger cohorts.

The remainder of the paper is structured as follows. The literature review identifies the development of the Internet and the utilization of social media in Indonesia. It also explores relevant research from other countries on how the Internet is impacting electoral results. Next, the data and measurement of the research are elaborated. The fourth section discusses the results of the analysis. A conclusion is presented in the final section, including implications for further studies on the impact of the Internet in contemporary Indonesian electoral politics.

\section{Literature Review}

Research on the impact of Web campaigning on voting behavior is evolving but is still in an early stage, and sometimes resulting contradictory conclusions (Porten-Cheé 2013). For example, the earliest empirical research on the effect of online campaign tools was observing the 1996 U.S. Presidential and Congressional Elections. Dave D'Alessio (1997) reports that candidates who ran a campaign website appeared to reach a higher number of votes. By 2000 , the use of cyber-campaign was spreading rapidly among candidates and local parties with over $90 \%$ of the major party candidates had a website (Gibson 2004). On the other hand, Park and Perry (2008) did not find that visiting political campaign websites had any impact on voting. Similarly, a study on Australian electoral politics suggests parties simply do not see a mass audience that are enthusiastic for e-politics, where only $4.4 \%$ of voters reporting that they used the Internet to get news about the 1998 federal elections (Gibson \& Ward 2002).

The presidential campaigns of Barack Obama in 2008 and 2012, which resulted in huge success, had brought out the importance of personalized political communication and the commodification of digital media as effective electoral tools (Bimber 2014; Cogburn \& Espinoza-Vasquez 2011; Gerodimos \& Justinussen 2015). Thus, cyber-campaigning has become an increasingly important in achieving victory in political race, and more candidates began to adopt this approach (Gibson \& Ward 2002; Gibson \& McAllister 2015; Roberts 2015; Koc-Michalska et al. 2016).

A bulk body of research conducted in the West have shown that the internet, and Web 2.0 in particular (the second generation Web characterized as interactive and participatory technologies, such as Facebook, Twitter, and YouTube), offers an important channel for politicians and parties to engage with their voters (Harfoush 2009; Cogburn \& Espinoza-Vasquez 2011; Lassen \& Brown 2011; Farrell 2012; Gibson et al. 2002). Gainous and Wagner (2013b) argue that unlike other mediums, the communications on the Internet can be immediate, with its distribution that can travel at speeds never seen before. In the following section, we are identifying the 
practice of cyber-campaign in Indonesia, the world's third largest democracy and home to around 130 million active Facebook accounts.

First connected in 1983, the internet usage in Indonesia continues to grow with an estimate national penetration of 50 percent, or only 3 points less than the world average, by 2018 (We Are Social 2018). Ordinary Indonesians are reportedly spending almost 9 hours per day on the Internet, only slightly lower than Thailand (9 hours 38 minutes), the Philippines (9 hours 29 minutes), and Brazil (9 hours 14 minutes). A joint Google-Temasek study predicted that Indonesia will have 215 million users by 2020 , making it the fourth-largest in the world. Thus, "Indonesia is not just 'joining' the Internet: the entire Internet is in the process of becoming more Indonesian," wrote Tony Keusgen, Country head, Google Indonesia (2016).

However, despite these enormous potentials, little is known on whether the Internet in Indonesia is playing a crucial role in political realm, especially on how parties are utilizing the Internet for virtual campaigning. Have they maximized websites and social media accounts up to its potential in gaining electoral support? And is there any correlation between parties' parliamentary size and the quality of their websites or their virtual popularity? This paper aims to contribute to the conversation by observing political parties ahead of the 2019 general elections.

More than 180 million registered voters will cast their votes to elect representatives for 4 levels of assemblies; the lower house (Dewan Perwakilan Rakyat/DPR), the upper house (Dewan Perwakilan Daerah/DPD), the provincial, and the city/municipality parliaments (Ramadan 2018a). As much as 16 parties are qualified to run, including 4 newly established parties. For the first time, the presidential election will also be taking place on the same day of the legislative elections. This makes next year elections are so important and interesting. Starting from September 23rd, 2018 until April 13th, 2019, all parties and candidates (both legislative and presidential) are running their campaigns. With an open proportional representation (PR) electoral system, voters can either elect a candidate or a party. Thus, unlike in the U.S. electoral system, (online) campaigning by parties is as important as by individual candidates.

Merlyna Lim (2013b) asserts millions of Indonesians, mostly young, have access to the Internet and they flocked into social media, making the country extremely big on Facebook and Twitter. A study by Tapsell (2017b) suggests it is not uncommon for Indonesians to create multiple Facebook accounts; one for unfiltered public, the other for people they know reasonably well. Often times, Indonesian users have more than 1,000 'friends', many of whom they have never met in person. He also argues that new, digital technologies are pulling Indonesia into two directions; (1) digitalization enables oligarchs to control the mainstream media and encourages a centralized elite power structure, (2) digital media are used by citizens for liberatory 
purposes, where ordinary citizens can challenge elite power structures by mobilizing others on social media (2017a).

According to the Digital Report 2018 published by We Are Social, the country has the world's 4th largest number of active Facebook users (130 million) and it is estimated 23 percent of the national population has at least one account with the networking site. Two cities, Bekasi and Jakarta, are currently sitting as the 3rd and 4th largest users with 18 million and 16 million active users, respectively. This domination is very likely to continue as the annual digital growth showing that 24 million new social media accounts had been created between $2017-2018$ or equals to $23 \%$ of increase. Nearly 3.5 hours per day are being spent on social media, and Indonesia is only topped by the Philippines and Brazil.

Social media is, without a doubt, has become so popular in the Southeast Asian countries, including Indonesia. Oftentimes "Facebook is the internet in south-east Asia" (Massola 2018). But to what extent has it been reflected on the political engagement? As we looked into the top 20 Google search queries in 2017, most users are searching for: (1) "download", (2) "lagu" (translated into English as "song"), and (3) "FB" (abbr. for Facebook--red). Meanwhile, the word of "news" occupies more down the track at 19th position, indicating Internet usage in Indonesia is dominated by entertainment and leisure purposes, not seeking information or as such.

Despite the significant volume of social media users in Indonesia, studies that investigate the impact of social media on Indonesian politics are still scant (see: Johansson (2016b)). Prior studies on the 2014 legislative elections have shown that parties had been using the Internet to gain political support (Alami 2013) and candidates with better resources would have team members who handled online and offline media campaigns (Aspinall \& Sukmajati 2015). Beers (2014), utilizing Twitter data ahead of the 2009 elections, finds that Partai Keadilan Sejahtera (PKS), Gerindra, and PDI-P are most likely to adopt rational-critical or mobilize interaction strategies. He further argues "the relatively modest Twitter presence of parties, suggesting that it remains an untapped resource for party-constituent interactions, but parties that have committed to using the medium have found responses (Beers 2014, p. 18)."

Using Twitter data on all winning candidates, Johansson (2016b) asserts that even though Twitter is a popular medium in Indonesia, relatively few politicians seem to have developed a clear media strategy for the platform. His research suggests there is no clear pattern of the intensity of Twitter use across the country, where some of the provinces with the highest percentage of the candidates using Twitter are located far from Java. For example, West Papua has the same percentage of winning candidates with a public Twitter account as Jakarta. He also contends that PKS is the political party with the largest share of candidates who were active on Twitter during 
the election period (65\%). On the contrary, Golkar has only $17.6 \%$ winning candidates who were active on Twitter.

\section{Data and Measurement}

Data for this research was taken from official websites and social media of 16 political parties contestants of 2019 Legislative Election provided by the General Election Committee (KPU) (see: https://kpu.go.id/index.php/pages/detail/2018/958). These parties are listed according to KPU parties list: Partai Kebangkitan Bangsa (PKB), Partai Gerakan Rakyat Indonesia (Gerindra), Partai Demokrasi Indonesia Perjuangan (PDI-P), Partai Golongan Karya (Golkar), Partai Nasional Demokrat (Nasdem), Partai Garuda (Garuda), Berkarya, Partai Keadilan Sejahtera (PKS), Partai Persatuan Indonesia (Perindo), Partai Persatuan Pembangunan (PPP), Partai Solidaritas Indonesia (PSI), Partai Amanat Nasional (PAN), Partai Hati Nurani Rakyat (Hanura), Demokrat, Partai Bulan Bintang (PBB), and Partai Keadilan dan Persatuan Indonesia (PKPI). Eleven parties (Gerindra, Nasdem, Garuda, Partai Berkarya, PKS, PSI, Hanura, Demokrat, PBB, PKPI) did not register their official websites to KPU. Data search was then conducted through Google using parties' names. Finally, we have a list of 16 parties websites URLs and social media contacts as of December 4th, 2018 to examine. Details of the list of political parties' websites and social media accounts, along with reported initial campaign funds can be found in Appendix 1. However, Hanura and PKPI websites were inactive during our observation period 23 September 2018-December 2018.

The data collection and analysis for this study based on the modified version of the coding scheme used by Gibson and Ward (2002) for the evaluation of functionality and delivery of websites. Then we simplified and categorized the features based on conceptual framework provided by Lilleker et al. (2011). As a result, the coding scheme for the websites comprised of 43 features under of four categories: information provision, mobilization, engagement, and technological sophistication (Table 1). Detail of measures for each function and the system of assigning the points was as follows. Functions included information provision (additive index 0-16, one point assigned for each item present), mobilization (cumulative index 0-19), engagement (cumulative index $0-n$ ), and technological sophistication (additive index $0-14$, one point assigned for each item present). Ranking of the party's website was done based on the points scored by each website according to the modified coding scheme. First, we rank the websites' quality in each category, and then combine all rankings into an overall ranking list. With the help of RStudio software, we also visualized party's online popularity on four social media platforms: Facebook, Twitter, Instagram, and YouTube.

Our focus in the content analysis of the main websites, or specific campaign website if one was built, conducted for 3 months since the campaign starts. We do not observe 
the content of the social networking sites (SNS), except in its relation to the website's linkage to the SNS. Our analysis is trying to answer a couple of questions; how do political parties use their websites for electioneering in Indonesia? How do the parties perform based on their websites' functionalities and delivery? Do the Indonesian political parties utilize their website up to its potential? What efforts do the Indonesian political parties make to engage the voters through websites and social media platforms? Is there any relationship between parties' parliamentary size and the quality of their websites and online popularity? 


\begin{tabular}{|c|c|c|c|c|c|}
\hline \multicolumn{2}{|c|}{ Information provision } & \multirow{2}{*}{\begin{tabular}{|l|} 
Mobilization \\
Donation index
\end{tabular}} & \multirow{2}{*}{\begin{tabular}{|l} 
Engagement \\
Openness
\end{tabular}} & \multicolumn{2}{|c|}{ Technological Sophistication } \\
\hline $\begin{array}{l}\text { Organizational } \\
\text { history }\end{array}$ & $\begin{array}{l}\text { Electoral } \\
\text { information }\end{array}$ & & & Graphics & Sitemap/index \\
\hline Structure & $\begin{array}{l}\text { Event } \\
\text { calendar }\end{array}$ & $\begin{array}{l}\text { Merchandise } \\
\text { purchase }\end{array}$ & Feedback index & Frames & Search \\
\hline Values/ideology & $F A Q$ & $\begin{array}{l}\text { Negative } \\
\text { campaigning }\end{array}$ & $\begin{array}{l}\text { Interaction } \\
\text { index }\end{array}$ & Moving icons & $\begin{array}{l}\text { Press release via } \\
\text { email }\end{array}$ \\
\hline Policies & Internal links & Credit claiming & Link to SNS & Sound & $\begin{array}{l}\text { Press release via } \\
R S S\end{array}$ \\
\hline $\begin{array}{l}\text { Documents } \\
\text { (manifesto) }\end{array}$ & $\begin{array}{l}\text { Partisan } \\
\text { links }\end{array}$ & $\begin{array}{l}\text { Targeting } \\
\text { index }\end{array}$ & & Video & Download podcast \\
\hline Newsletters & $\begin{array}{l}\text { Reference } \\
\text { links }\end{array}$ & Join email list & & Live streaming & \\
\hline Media releases & & $\begin{array}{l}\text { Download } \\
\text { campaign tools }\end{array}$ & & $\begin{array}{l}\text { Text } \\
\text { option } \\
\text { site) }\end{array}$ & \\
\hline People/who's who & & & & $\begin{array}{l}\text { Home page } \\
\text { icon on lower } \\
\text { level pages }\end{array}$ & \\
\hline Leader profile & & & & $\begin{array}{l}\text { Fixed menu bal } \\
\text { on lower-leve } \\
\text { pages }\end{array}$ & \\
\hline Candidate profiles & & & & & \\
\hline
\end{tabular}

Table 1. The coding scheme for political parties' websites adopted from Gibson and Ward (2002).

\section{Findings and Discussion}

\subsection{Parties Websites}

There are 14 parties' websites, excluding Hanura and PKPI, observed in our study. The following paragraphs present the findings of the study. The detail points scored by each website in each category are shown in the party websites scoring sheet (see Appendix 2). Table 2 below exhibits the overall ranking for parties based on their websites' performance on four categories. 


\begin{tabular}{|c|c|c|c|c|c|}
\hline $\begin{array}{l}\text { Overall } \\
\text { ranking }\end{array}$ & $\begin{array}{l}\text { Political } \\
\text { Party }\end{array}$ & $\begin{array}{l}\text { Informatio } \\
\mathbf{n} \\
\text { provision }\end{array}$ & Mobilization & Engagement & $\begin{array}{l}\text { Technological } \\
\text { sophistication }\end{array}$ \\
\hline 1 & PKS & 3 & 2 & 1 & 2 \\
\hline 2 & Golkar & 1 & 4 & 3 & 3 \\
\hline 3 & Berkarya & 4 & 3 & 5 & 4 \\
\hline 4 & PSI & 2 & 1 & 13 & 1 \\
\hline 5 & PDI-P & 5 & 5 & 6 & 5 \\
\hline 6 & Perindo & 12 & 8 & 2 & 6 \\
\hline 7 & PAN & 8 & 10 & 4 & 10 \\
\hline 8 & Gerindra & 9 & 6 & 7 & 11 \\
\hline 9 & PKB & 6 & 12 & 9 & 7 \\
\hline 10 & Demokrat & 7 & 9 & 11 & 9 \\
\hline 11 & PPP & 13 & 7 & 8 & 12 \\
\hline 12 & Garuda & 14 & 14 & 10 & 8 \\
\hline 13 & PBB & 10 & 11 & 12 & 13 \\
\hline 14 & Nasdem & 11 & 13 & 14 & 14 \\
\hline
\end{tabular}

Table 2. Indonesian political parties ranking based on their websites' overall performance (Source: authors' tabulation). 


\subsubsection{Information Provision}

The main purpose of political party website is to provide credible documentary sources and information about the party to the public. Website is also a fact-checking tool to corroborate information provided by the fast but hoax-prone social media. Despite our high expectation, the overall mean score for information provision features is quite low; 8.1 from a maximum score of 16 . A well-established party, Golkar, ranked first with 14 points, and followed by a newcomer, PSI, with 11 points. All parties tend to focus on organizational information and news related to party's activities, but less on their policies and political stances. Moreover, only 3 (Berkarya, PSI, and PBB) from 14 parties dedicate specific webpage for 2019 electoral information. Concurrently, there are more information on party's leaders than candidate profiles. The overall scores reflect the underutilization of website as information provider by Indonesian political parties.

Many parties have moved from merely using text-based content to a more engaging format of delivering information. For instance, video profile has been used widely to present profiles of party and its leaders. However, there is no party utilizing a Frequently Asked Question (FAQ) feature, which is one of credibility tools for information-oriented website (Danielson 2006; Fogg 2002).

\subsubsection{Mobilization}

Website enables political parties to mobilize financial support and membership through online platform and issue campaign. Despite parties' reliance on state subsidy, 7 out of 14 political parties have started designing link for public donation. In addition, PSI has created online shop for merchandise purchase. Likewise, half of the parties' websites begins to allow online membership registration. PSI scores the highest in the overall mobilization score (14), and PKS comes after that (11). Both parties often claim as the party for the millennials by maximizing their online visibility and engaging taglines. Meanwhile, the remaining parties score below half of maximum score of 9.5 .

The use of issue campaign shown in targeted index is very low (average 1.9 from a maximum score of 6). Some parties use their news feature to address issues related to certain targeted groups, for instance women and youth, but in overall, most parties dedicate their campaign more on trending topics for general audiences. Women's parliamentary representation in Indonesia has been low and meagre among Asian countries (Prihatini 2018). This low score confirms the transition of Indonesian political parties of the post-Reformasi from ideological clustering and socio-cultural voter-based into what Mietzner (2008) defines as catch-all parties. 


\subsubsection{Engagement}

Almost all parties' websites provide email contact list, comment form, various audiovisual elements, and sharing features, which encourage visitors to engage with the sites. Moreover, the utilization of these tools enables visitors to experience a degree of ownership over the campaign (Harfoush 2009). PKS scores highest in all engagement features including in its openness, of which PKS lists a very extensive website networks and email contacts of its district representatives throughout the country. Meanwhile, PSI prefers to provide telephone numbers of each local representatives. However, more than $80 \%$ of political parties use a centralized mode of engagement by providing a single contact of their Jakarta office.

Parties tend to be transitioning from relying on website to social media and mobile apps for their political engagement. Almost all parties display links to their social media in their websites, but only 6 parties use social media aggregator to pull their social media posts in the websites. Also, mobile apps have become popular tool for internal party engagement. To the best of our knowledge, political parties in Indonesia have developed mobile apps since the medio 2017. People can download it into their smartphones and received many features, such as newsfeed, party's official song, and expand their social media interaction for the campaign. Not only parties, many candidates develop their own mobile app too. From 14 parties we observed, only PKS put the download link in its website for its official mobile app, which has been downloaded more than 1,000 times per December 2018. The use of mobile app for political engagement in Indonesia can become more significant in the future as mobile penetration (unique users vs. total population) is $67 \%$, with estimated number of unique mobile users (any type of handset) to be as nearly as 178 million (We Are Social 2018).

\subsubsection{Technological Sophistication}

Our study reveals that there is no huge technological gap between parties' websites. Almost all of them are using motion graphics and videos to make the websites to be more interactive. Podcast and video live streaming are rarely used, and email subscription is the most common method to share website update. Contrary to the previous assumption, for instance Lilleker et.al (2011), our finding shows that the technological sophistication is not dependent on parties' financial and human resources. Major parties' websites, such as PDI-P, which has 105 billion IDR initial campaign fund, does not outperform PKS, which only has 17 billion IDR for the 2019 campaign (see Table 3). Similarly, PBB with fairly equal initial campaign funds with PKS performs far less impressing in utilizing the digital media platforms. 
Political Parties in Indonesia and the Internet: A Comparative Analysis

\begin{tabular}{|c|c|c|c|}
\hline $\begin{array}{l}\text { Ranking on } \\
\text { technological } \\
\text { sophistication }\end{array}$ & Party & Seats & Reported initial campaign funds \\
\hline 1 & PSI & -- & $577,474,910$ \\
\hline 2 & PKS & 40 & $17,091,025,000$ \\
\hline 3 & Golkar & 91 & $110,000,000$ \\
\hline 4 & Berkarya & -- & $28,636,420,000$ \\
\hline 5 & PDIP & 109 & $106,143,479,741$ \\
\hline 6 & Perindo & -- & $1,000,000$ \\
\hline 7 & PKB & 47 & $15,235,981,000$ \\
\hline 8 & Garuda & -- & $1,000,000$ \\
\hline 9 & Demokrat & 61 & $839,400,000$ \\
\hline 10 & PAN & 49 & $50,000,000$ \\
\hline 11 & Gerindra & 73 & $75,260,112,183$ \\
\hline 12 & PPP & 39 & $510,000,000$ \\
\hline 13 & PBB & -- & $16,421,530,059$ \\
\hline 14 & Nasdem & 35 & $5,536,250,000$ \\
\hline N/A & Hanura & 16 & $13,000,000$ \\
\hline N/A & PKPI & -- & $360,000,000$ \\
\hline
\end{tabular}

Table 3. Indonesian political parties ranking based on their websites' technological sophistication (Source: authors' tabulation).

Furthermore, parties have not used the advancement website technology to its potential. Technology such as multilingual, RSS feed, and the visually impaired web user's technology are missing from most of websites observed, and only PKS uses multilingual function. This function enables PKS websites to be read in English and 
Arabic beside in Bahasa Indonesia. Additionally, there is only one party, PSI, who uses RSS feed for its website.

\subsubsection{Overall Political Parties Websites assessment}

Since the first online campaign in 1996 US Presidential election (Stromer-Galley 2014), the World Wide Web has evolved dramatically. Website technology has enabled political parties to provide information, mobilize, and engage the voters in more interactive ways. The cost of building website has decreased significantly, which makes all parties can now compete on a level playing field. Despite of this development, political parties in Indonesia are not using their websites up to its potential, particularly in relation to the 2019 elections. The average scores are below the median scores of all 4 measurement variables. Most websites even score poorly in the basic function of information provision. The vast majority of parties' websites are focusing on the party and party leaders' profiles instead of giving sufficient electoral information on the upcoming elections candidates. However, the use of motion graphics, videos, and other interactive technology have given depth to the information they provided. These are the most common technology used by the parties. We argue that Indonesian political parties tend to focus on certain aspects of information rather than its scope.

The mobilization features of website are still used in a very early stage. Its development will depend on external factors rather than the development of website technology itself. The availability of financial subsidy from the state and electoral system will be more influential in the modes of political mobilization. In addition, the utilization of mobilization and engagement features of the websites seem to be reduced by the prevalent usage of social media and mobile app in the country. Nonetheless, the social media is prone to misinformation and biases, and mobile app is only useful to reach out voters who already have preferences. The next challenge for internet campaign will be how to optimize these tools including website to achieve the political objectives.

Our findings display a mixed result related to parties' websites qualities. There are no differences between older and newer political parties in their utilization of website for their 2019 online campaign. Both older and new parties occupy the best five on our ranking system. PKS ranks highest in the overall website assessment, followed by Golkar, Berkarya, PSI, then PDI-P. Financial resources and the current parliamentary size of political parties seem to have no relationship with the quality of the websites.

The ability of PKS and PSI in capitalizing the online presences of their individual members seems to be the key for their high-quality websites. Almost all district representatives of PKS have their own websites, and almost all PSI leaders have their 
strong online presences. Also, most of the members of both parties are young people and well-versed in world wide web. PSI, in particular, uses its cyber campaign to fill the gap in its physical presence. On the contrary, Golkar's website sophistication appears to be an online representation of its long history and its well-structured nationwide physical network.

\subsection{Social Media}

\subsubsection{Utilization}

Based on our observation on Indonesian political parties' official social media accounts ahead of the 2019 general elections, a couple of important findings will be discussed in the following section. Firstly, it is evident that all parties in Indonesia, except PKPI, are using social media as a tool to disseminate their campaign materials and to promote their exposure to the wider public. Yet, the utilization and the performance of parties' social media platforms is rather diverse. Most parties are using four platforms; Facebook, Twitter, Instagram, and YouTube, with only five parties that do not have a YouTube account/channel.

The following graph shows the average of party's age in Indonesia is slightly less than 20 years old. Half of parties competing in next year elections are between 10 to 20 years old, and only 2 out of 16 parties (12.5\%) were established more than 40 years ago. This exemplifies just how young democratization in Indonesia is. This is partly because the new era of Reformasi, which offers an open and direct democracy following the end of Suharto's authoritarian regime, only started in the last two decades. 

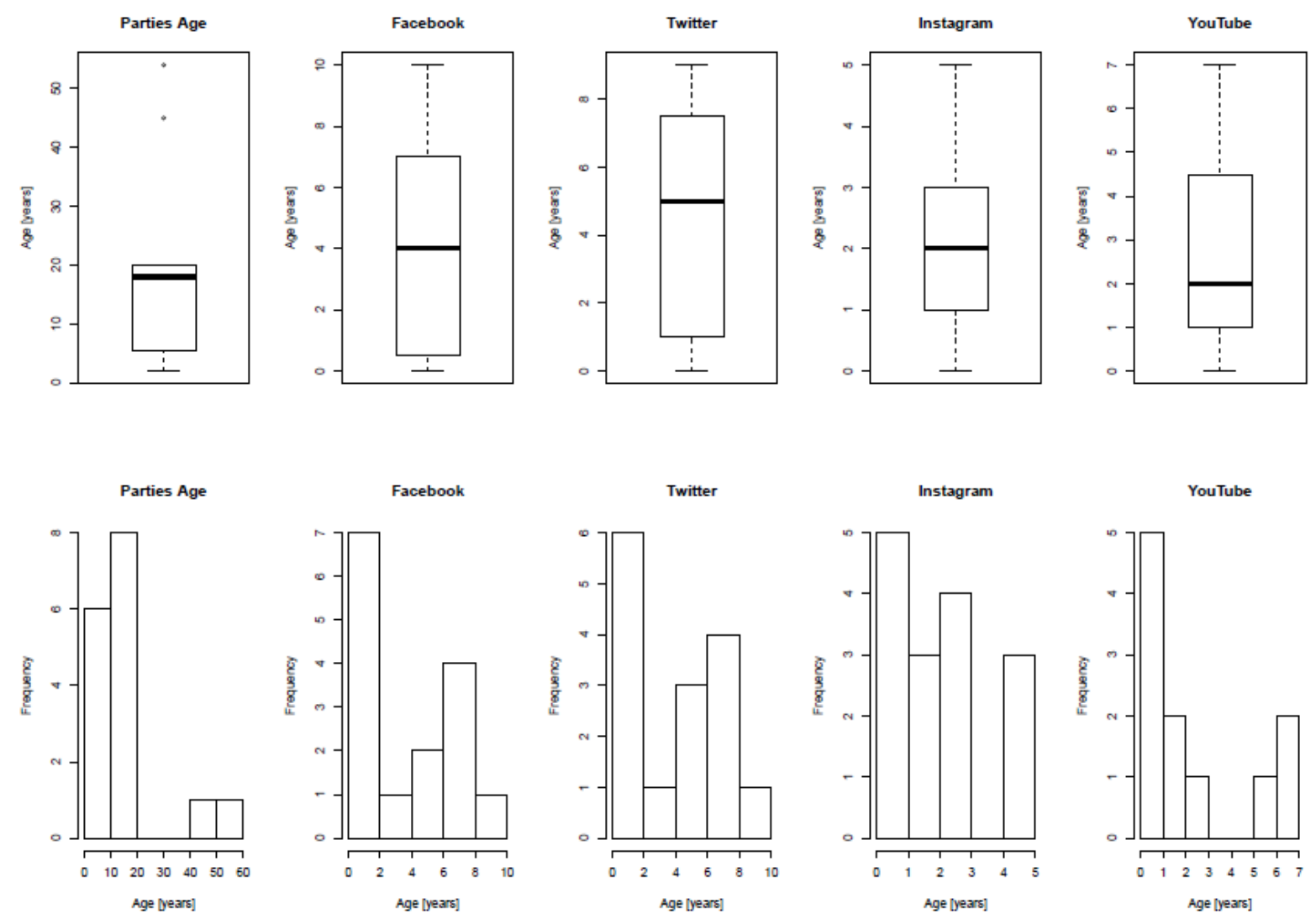

Figure 1. Parties Age and the Utilisation of Social Media (Source: authors' calculation)

Indonesia, to date, has held 4 general elections. In 1999, 48 parties participated and only 18 succeeded to enter the parliament. The next election in 2004 were joined by 24 parties, and 16 became parliamentary parties. In 2009, the number of participating parties experiences a hike that reached 38. However, only 9 managed to send legislators following a $2.5 \%$ parliamentary threshold. The latest election in 2014 was joined by 12 national parties and 3 local Aceh parties. With a higher parliamentary threshold (3.5\%), there was only 10 parties eligible to represent their constituents (KPU 2014). In the next election, 4 out of 16 (25\%) parties competing for 575 DPR seats are only established in 2014 onwards.

In average, Indonesian parties had been using Facebook for 4 years, Twitter for 5 years, and Instagram as well as YouTube for 2 years. This brings the overall average age of social media platforms to 3.25 years. The finding suggests that Twitter is the most established social media platform being used by Indonesian parties, with five of them have been using it for more than 6 years. PDI-P is a party that pioneered the use of Facebook, as it joined the social network site since 2008. Meanwhile, PAN has joined Facebook in the last 8 years, followed by PKS whose account has been 
registered for 7 years. However, it is interesting to note that despite being the first three parties that created Facebook accounts, PDI-P, PAN, and PKS's popularity on Facebook is much lower than Gerindra and PSI (see Figure 2). PDI-P's Facebook popularity, measured by the number of likes, is less than half of Gerindra's, which has more than 3.6 million likes. Similarly, PSI, a newly established party targeting young voters, has 1 million more likes than PDI-P. These findings indicate Gerindra and PSI had been very successful in gaining online popularity, especially on Facebook.
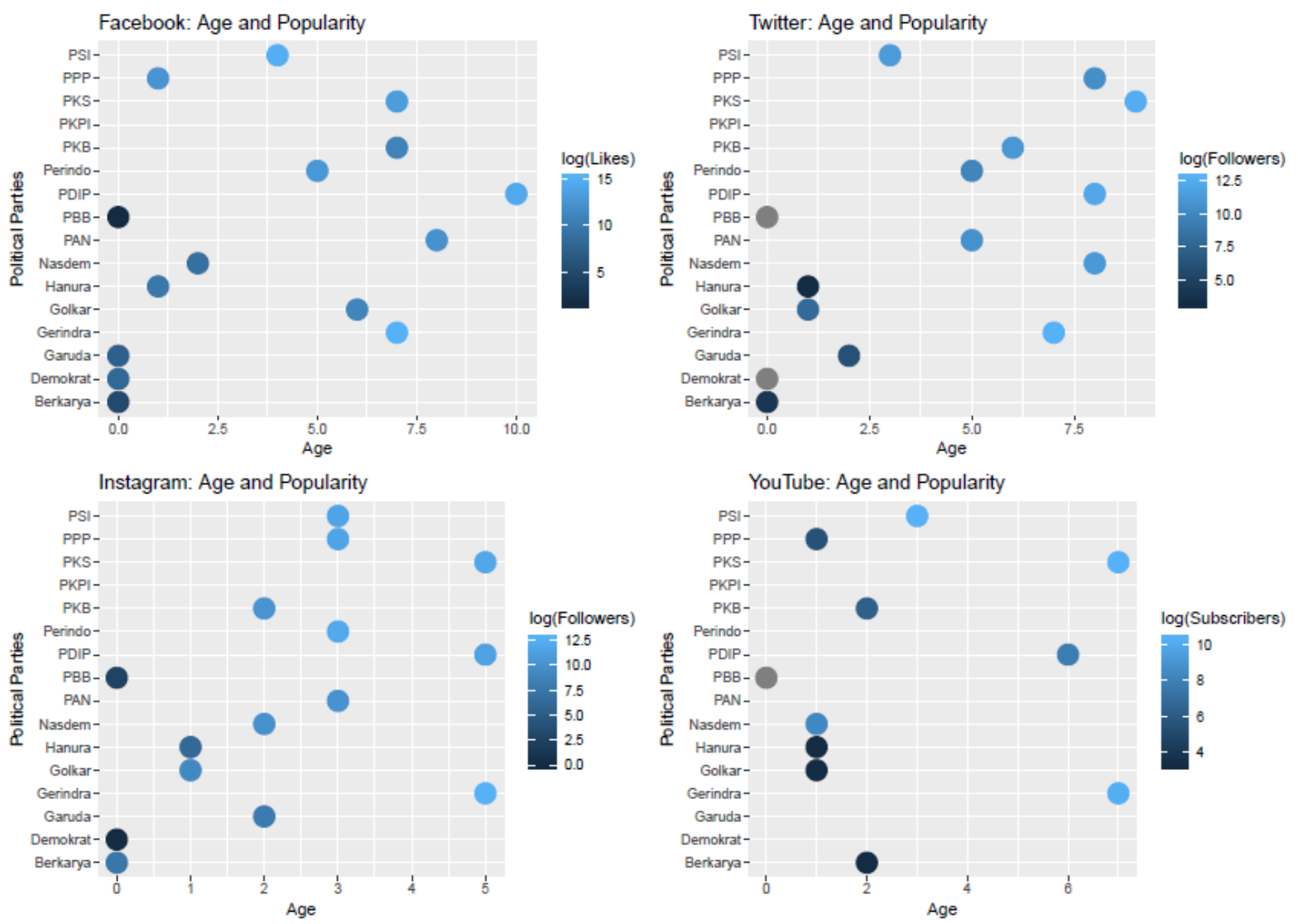

Figure 2. Social Media: Age and Popularity (Source: authors' calculation).

On the other hand, PKS has been a prolific Twitter user in the last 9 years. Yet, despite being the pioneer on Twitter utilization, the number of followers is 90,000 less than Gerindra, whose account with Twitter is two years younger. Another starking contrast between these accounts is that Gerindra is following more than 4,000 Twitter IDs, while most parties keeping an eye on less than 1,000. Gerindra is also very popular on Instagram, having most followers and joined the platform on the same year as PDI-P and PKS, in 2013. An interesting finding from observing parties' Instagram accounts is that Perindo, a party created and led by a Chinesedescent media mogul Harry Tanoesoedibjo, happens to be the second most popular 
party on Instagram. It outnumbered PDI-P and $\mathrm{PKS}^{\prime}$ followers which joined the channel two years earlier.

The graph also displays that 5 out of 16 (31\%) parties had no official YouTube channel. This suggests YouTube has not received significant interests from parties' elites as a platform to transmit political messages and propaganda. The analysis suggests PSI is the most popular party on YouTube, although it has only been using the channel for three years. Earlier starters like PKS and Gerindra who began posting their videos 7 years ago occupy the second and the third spots respectively.

\subsubsection{Age}

Secondly, this study finds that parties' age does not determine parties' online popularity. In other words, younger parties can have significantly more Facebook likes or Twitter and Instagram followers than the older ones. Figure 3 exhibits how Gerindra, established only 10 years ago, has the most likes and followers on all social media platforms except YouTube. Older parties like Golkar and PPP are far less successful in garnering online support. Similarly, PDI-P as the winner in 1999 and 2014 elections has not been extremely popular on social media. This finding seems contradictory to the reported interest of the party, where issues related to social media was discussed in the 2012 PDI-P national assembly (Alami 2013). 

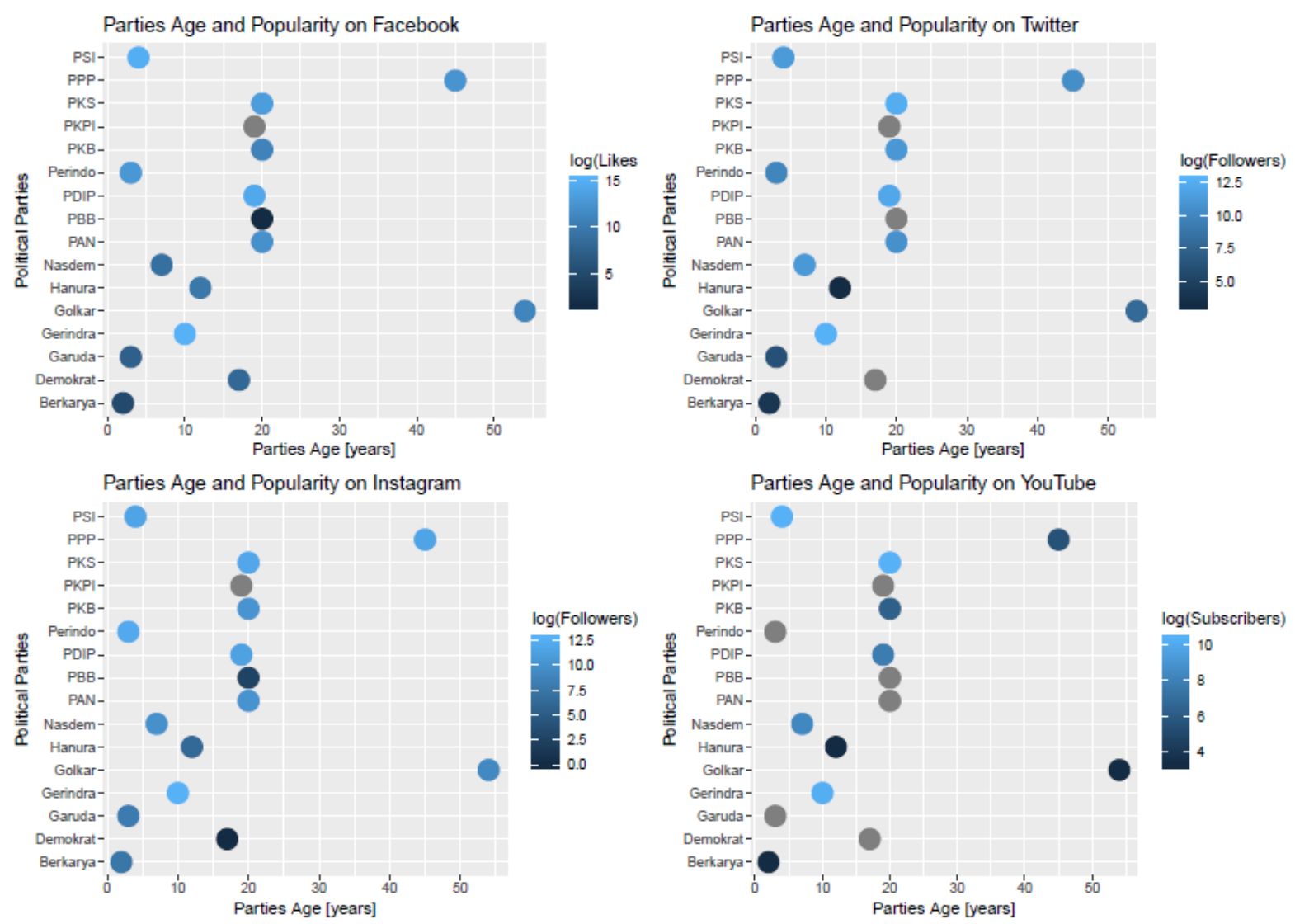

Figure 3. Parties Age and Online Popularity (Source: authors' calculation).

With these findings, we argue that established parties in Indonesia continue to engage with their constituents without heavily relying on social media. Their electoral success can still be satisfactory through massive offline campaigns. The fact that out of 5 parties which received more than 10 million votes in 2014 legislative elections, only 2 has $>1$ million likes on Facebook and $>100,000$ followers on Twitter suggests that Indonesian voters are not yet utilizing social media as a platform to express their political preferences. Also, among the 5 parties, only 1 that has $>300,000$ Instagram followers and $>20,000$ YouTube subscribers. Therefore, this study has found a relatively weak correlation between parties' online popularity and electoral performance.

\subsubsection{Parliamentary Size}

The next analysis relates to parties' parliamentary size and the utilization of social media channels. Figure 4 shows that out of 6 parties that has more than 40 seats in DPR, Golkar, Demokrat, and PAN are parties that had not massively work on voters via social media. Meanwhile, the majority of parties with smaller parliamentary size has only recently created their presence on the social network sites. 

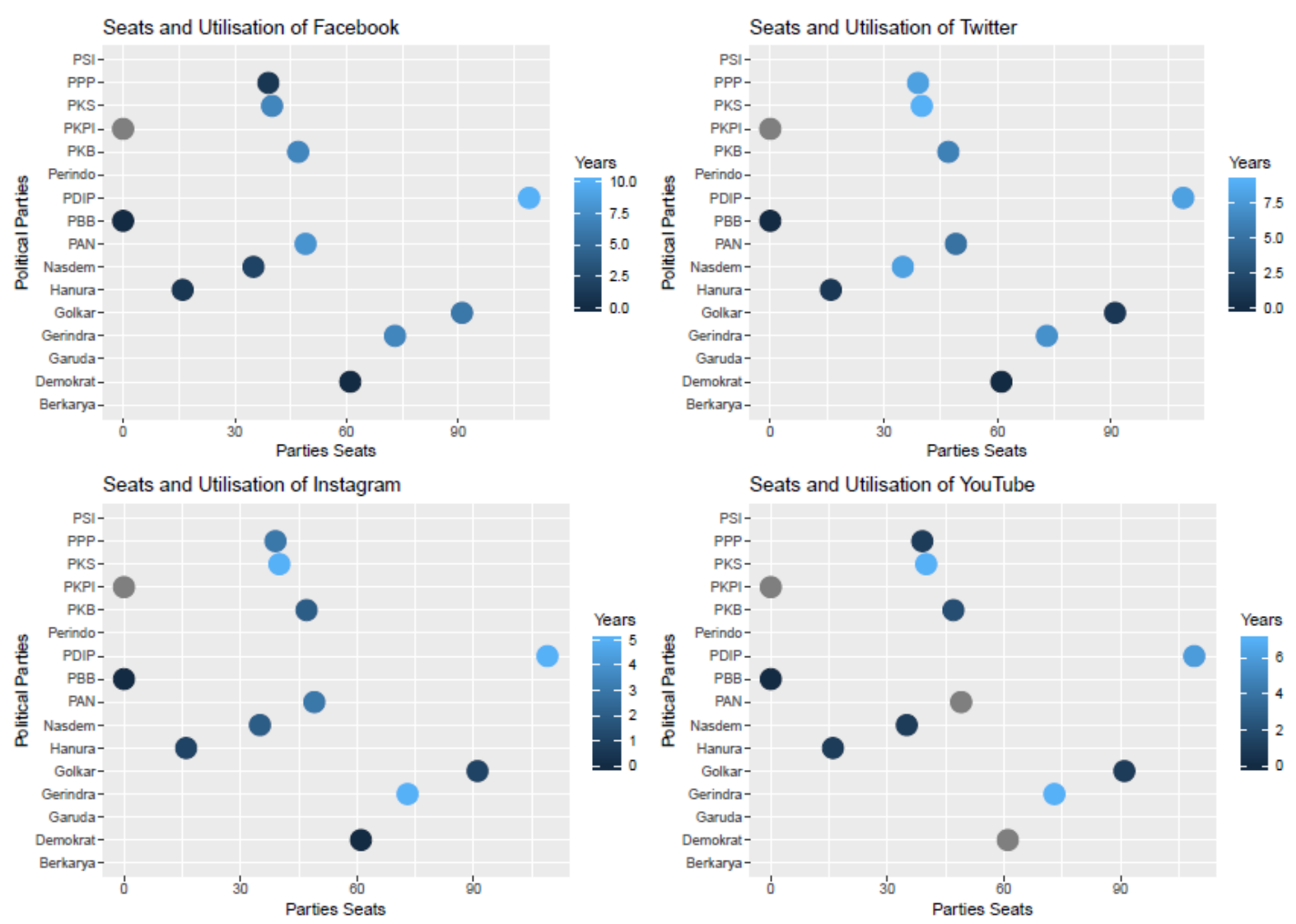

Figure 4. Parties Seats and the Utilisation of Social Media (Source: authors' calculation).

Golkar, as one of the most established parties in Indonesia, has not capitalized the Internet to promote their political messages to the wider public. The party reported multiple social media accounts to the Electoral Commission (KPU), yet, the popularity of the accounts is relatively low compared to the average scores. It is interesting to note that the Facebook button on the party's website is actually a broken link. This shows that the administrator is not paying a careful maintenance to the site. Likewise, the YouTube channel displays the former chairman Setya Novanto with only 26 subscribers. Golkar seems to come quite late in utilizing the Internet, as their Facebook and Twitter accounts with most likes and followers were only created in 2012 and 2017 respectively. Unlike most parties competing in the 2019 elections, Golkar did not report any YouTube channel.

This poor utilization of Internet by Golkar has raised the interest of the party's elites. Seven months heading to the 2019 elections, Airlangga Hartanto as the Chairman of Golkar asserted that his party would start working on a serious strategy for campaigning on the internet in order to gain support from the millennial voters (Perdana 2018). Similar concerns emerged in 2014 when Akbar Tanjung, one of 
prominent Golkar leaders, expressed the party's willingness to form a social media team up to the regional level (Alami 2013). However, our findings suggest Golkar continues to lacking in effectively campaigning using social media platforms.

Nasdem is a party created by a media mogul, Surya Paloh, who is also a splinter from Golkar. The party did not submit any official social media account to the KPU. However, for the purpose of this study, the analysis will be using the party's website and social media buttons available on the top right of the main page. The Facebook page, @OfficialNasDem, was first created in the end of November 2016 which was initially named as "Kita Indonesia". The page then changed into "Restorasi Indonesia" in February 2017, and again renamed as "Partai Nasdem" in November 2018. It now has around 8,000 followers and likes.

An Islam-based party, PPP, has one official account for each social media platform; Facebook, Twitter, YouTube, and Instagram. Interestingly, the Instagram button on the website brings us to the Chairman's account. Practically, postings are being dominated by Muhammad Romahurmuziy's activities. Probably this choice was taken based on a pragmatic approach, as his account on the Instagram is four times more popular than the party's official account (@dpp.ppp) with 104,000 and 26,200 followers respectively.

Another party observed in this study is Hanura. Created in 2006 by a handful of Golkar splinters and former military generals like Wiranto, the Chairman for 20062016. Effectively since December 2016, Oesman Sapta Odang (OSO), who is also the Speaker for DPD replaced Wiranto and became the leader of the party. The main page of the website shows the buttons to social media accounts managed by the party, yet the popularity is very low. The website, www.hanura.or.id, is no longer available since mid-December 2018. This situation is a setback for Hanura, as in 2014 the party's presence

Next is Demokrat, the winner in 2009 elections. The founder who is also the current Chairman, Susilo Bambang Yudhoyono (SBY), was directly elected as president for two consecutive terms (2004-2009 and 2009-2014). He and his wife are very active in social media, yet Demokrat as a party has failed to engage with the country's massive Internet population. One key evidence to support this assertion is the absence of links to social media accounts on the party's official website www.demokrat.or.id. Among all parties' websites observed in this study, only Demokrat has no social media buttons. Thus, to gain reliable data on Demokrat's official social media accounts dedicated for the 2019 election, the authors examined the list of social media accounts reported by the party to the Electoral Commission (Ramadan 2018b). 

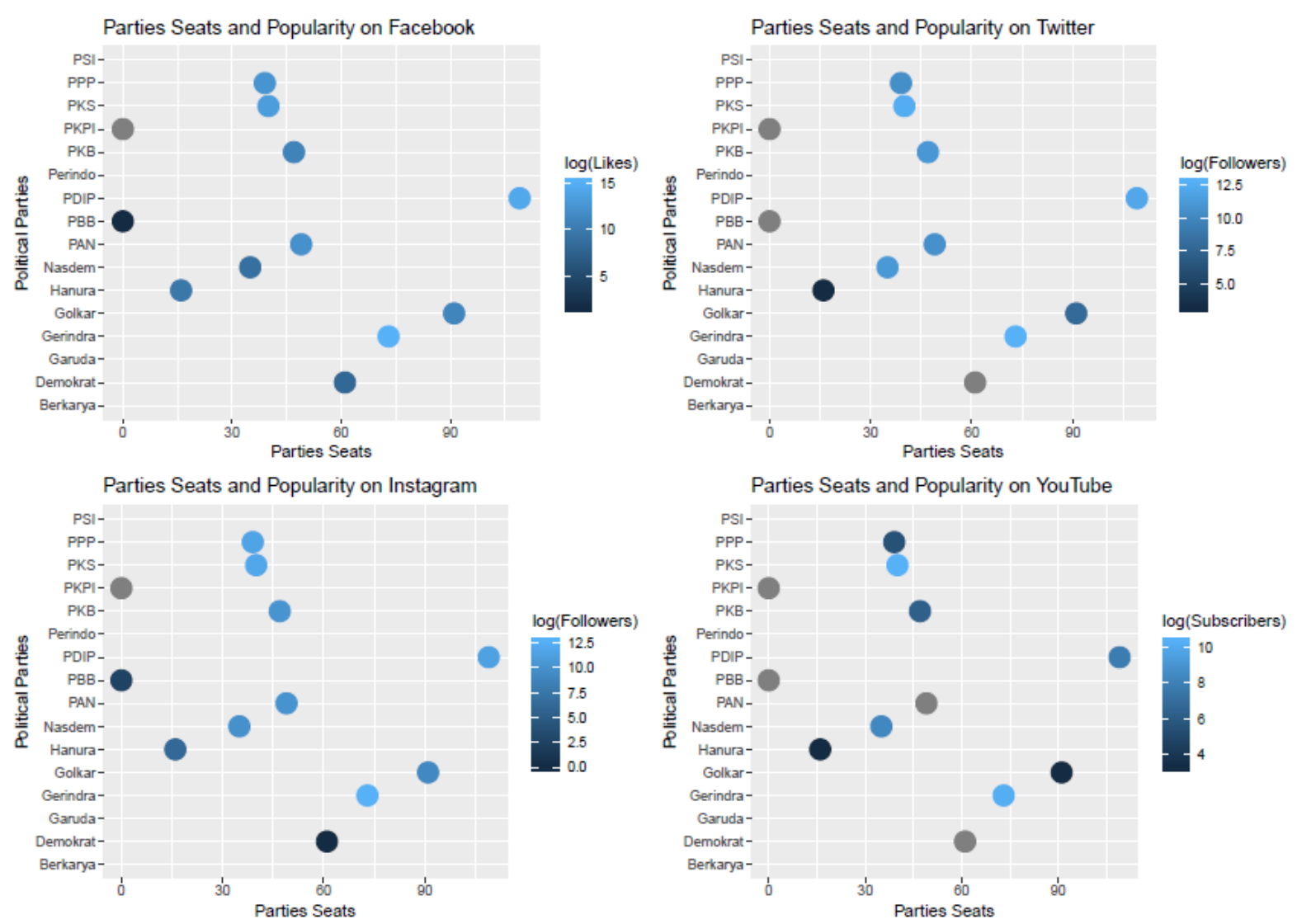

Figure 5. Parties Seats and Online Popularity (Source: Authors' calculation).

The results suggest that instead of using a Facebook account which was created in 2011 and has over 192.000 likes/followers (@pdemokrat), the party chose to create multiple new accounts with far less significant popularity (@demokrats14p with 3,500 followers/likes and @calegPDemokrat only has 70 followers). Furthermore, on Twitter, Demokrat's accounts dedicated for the 2019 elections; @PDS14P, @S14P, and @demokrat1414 had either only two followers, suspended, or not found, and all were created in 2018.

Demokrat is pursuing their campaign strategy utilizing a new "code" which was derived from the party's list position on the ballot sheets for next year elections: 14 . The wording is then "S14P" (read: "siap") which can be freely translated into English as "ready". The narration behind this new code suggests that Demokrat is ready to win the race as all social media accounts recently created are using this "S14P". Interestingly, the party runs another official account on Twitter since 2011 (@PDemokrat) with around 88,500 followers and 10,600 tweets. Similar condition is happening with Demokrat's Instagram account. All registered Instagram accounts (@PDS14P, @demokrat1414, @S14P) had only 1 to 3 followers and never posted a single thing. 
The decision to register such accounts to KPU is troubling as it sends a strong signal that the Demokrat elites are not paying a careful attention about how the online political campaign works. In order to maintain people's engagement and to enhance their loyalty to the party, social media accounts need to be always consistent so the number of followers or likes can continue to grow. However, this is not unique to Demokrat. Other parties, like Hanura, had reported much newer accounts on social media to KPU as their official social media for the 2019 elections rather than maintaining the more established accounts with far more significant number of followers and likes.

\subsubsection{Correlation: Seats and Online Popularity}

As we have discussed in this study, Indonesian parties are in a transition stage which leads to the use of digital media as a tool to disseminate information. Parties have different levels of interest when it comes to their online popularity. Some parties might not yet consider having significant Facebook likes of Twitter followers as that important. And thus, we can see their strategies in utilizing social media are varied.

We then pose a question about the correlation between parties' seats in parliament and their popularity on social media. Are these correlated? How weak or how strong is the correlation? Using the corrplot package available in RStudio, we can then visualize the correlation matrix between parties' seats, the age of their social media accounts (i.e. F_A refers to Facebook account age), and the number of followers/likes/subscribers (i.e. T_F means followers on Twitter). The following graph suggests that parties' seats only has a strong and positive correlation (0.67) with Facebook account age. Meanwhile, parties' age has a weak and negative correlation with the number of Facebook likes/F_L (-0.22) and YouTube subscribers/Y_S (-0.21). This means older parties are less popular in Facebook and YouTube compared to the younger cohorts. 


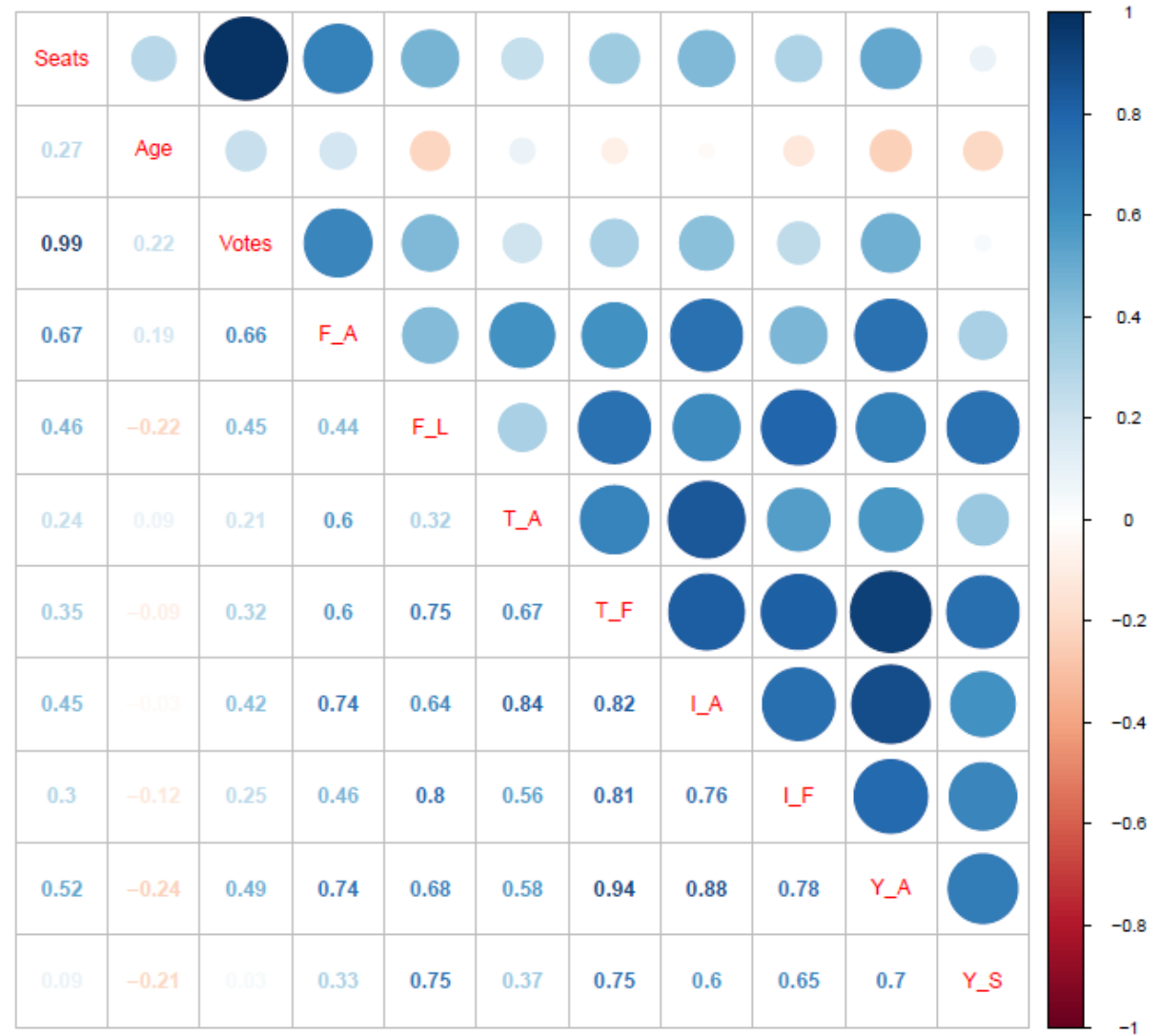

Figure 6. Correlation Matrix: Seats and Online Popularity (Source: authors' calculation).

Another important takeaway from the matrix is that parties' popularity on different social media platforms has a strong and positive correlation. The number of Facebook likes is in line with the volume of Instagram followers/I_F (0.80). Same goes with YouTube subscribers and Twitter followers, scored 0.75 . Interestingly, parties' Facebook account age and the number of likes has a weaker correlation score $(0.44)$ compared to Instagram account age/I_A and Instagram followers (0.76) or in YouTube (0.7) and Twitter (0.67). Thus, we argue that the pace in gaining popularity is different depending on the type of social media. Facebook appears to have a slower pace compared to other social media platforms in terms of growing public interest or support.

\section{Conclusion}

Indonesian open and free democracy is still very young, considering parties age in average sits at slightly less than 20 years old. For the upcoming 2019 general elections, $25 \%$ of participating parties are just created in 2014 onwards. On the other hand, Indonesia's growth in the utilization of Internet has offered the opportunities for all parties to expand their campaign into a more virtual approach. With more than 
100 million Internet users recorded in 2016, it is not exaggerating if one would suggest that Indonesian politics would be very closely influenced by the dynamics taking place in the Web. However, as this article suggests, the number of academic works on this particular research area is low. This paper aims to fill this gap in the literature by observing political parties' performance and popularity on the Internet, measured by their website's delivery and social media presence.

The first section of this paper finds that political parties in Indonesia are not using their websites up to its potential as the average points for 4 variables observed are lower than half of the maximum possible scores. Most websites even score poorly in the basic function of information provision. Furthermore, the vast majority of parties' websites are focusing on the party and party leaders' profiles instead of giving sufficient electoral information on the upcoming elections candidates. In the second part of the analysis, we have demonstrated that despite public's huge interest on multiple social media platforms, on average, Indonesian parties had only been using Facebook for 4 years, Twitter for 5 years, and Instagram for 2 years. The study identifies some gaps between parties in terms of the magnitude and growth of online popularity. It also finds that younger parties can have significantly more Facebook likes or Twitter and Instagram followers than the older ones.

While some of our findings corroborate previous studies (Johansson 2016a; Alami 2013; Beers 2014), this study expands the discussion by visualizing the index and correlation matrix between relevant aspects on Indonesian parties in the Web. The paper limits the focus on content analysis of websites of Indonesia parties ahead of the 2019 elections only. The analysis on social media was also limited to describe the trend, but not exploring the reasonings behind it. Future observation could consider the questions related to what factors determine the popularity of parties' social media accounts? Which approach should parties taking into consideration if they wish to improve their virtual campaigning performance? A quantitative study on voters' interest in liking of following a party on social media could also an interesting observation as part of our attempt to better understand the utilization of the Internet in Indonesian electoral politics. 


\section{References}

Books

Aspinall, E. \& Sukmajati, M. eds., 2015. Politik uang di Indonesia: patronase dan klientelisme pada pemilu legislatif 2014 [Money politics in Indonesia: patronage and clientelism in the 2014 legislative elections], Yogyakarta: PolGov UGM.

Danielson, D.R., 2006. Web Credibility. Encyclopedia of Human Computer Interaction, pp.713-721.

Enli, G.S. \& Moe, H. eds., 2017. Social Media and Election Campaigns: Key Tendencies and Ways Forward, New York: Routledge.

Gainous, J. \& Wagner, K.M., 2013a. Social Media-The New Dinner Table? In Tweeting to Power: The Social Media Revolution in American Politics. New York: Oxford University Press.

Gainous, J. \& Wagner, K.M., 2013b. Tweeting to Power: The Social Media Revolution in American Politics, New York: Oxford University Press.

Harfoush, R., 2009. Yes We Did! An inside look at how social media built the Obama brand, Indianapolis: New Riders.

Stromer-Galley, J., 2014. Presidential Campaigning in the Internet Age, Oxford: Oxford University Press.

Tapsell, R., 2017a. Media Power in Indonesia: Oligarchs, Citizens and the Digital Revolution, London: Rowman \& Littlefield International.

$\underline{\text { Journals }}$

Alami, A.N., 2013. Menakar Kekuatan Media Sosial Menjelang Pemilu 2014 [Measuring the Strength of Social Media Ahead of the 2014 Election]. Jurnal Penelitian Politik, 10(1), pp.85-99.

Beers, S., 2014. Shallow or Rational Public Spheres? Indonesian Political Parties in the Twitter-Sphere. The Journal of the South East Asia, 6(2), pp.1-23.

Bimber, B., 2014. Digital Media in the Obama Campaigns of 2008 and 2012: Adaptation to the Personalized Political Communication Environment. Journal of Information Technology \& Politics, 11(2), pp.130-150.

Cogburn, D.L. \& Espinoza-Vasquez, F.K., 2011. From Networked Nominee to Networked Nation: Examining the Impact of Web 2.0 and Social Media on Political 
Participation and Civic Engagement in the 2008 Obama Campaign. Journal of Political Marketing, 10(1-2), pp.189-213.

D'Alessio, D., 1997. Use of the World Wide Web in the 1996 US election. Electoral Studies, 16(4), pp.489-500.

Farrell, H., 2012. The consequences of the Internet for politics. Annual Review of Political Science, 15, pp.35-52.

Gadekar, R., Thakur, K. \& Ang, P.H., 2011. Web sites for e-electioneering in Maharashtra and Gujarat, India. Internet Research, 21(4), pp.435-457.

Gerodimos, R. \& Justinussen, J., 2015. Obama's 2012 Facebook Campaign: Political Communication in the Age of the Like Button. Journal of Information Technology \& Politics, 12(2), pp.113-132.

Gibson, R.K., 2004. Web campaigning from a global perspective. Asia-Pacific Review, 11(1), pp.95-126.

Gibson, R.K. \& McAllister, I., 2015. Normalising or Equalising Party Competition? Assessing the Impact of the Web on Election Campaigning. Political studies, 63(3), pp.529-547.

Gibson, R.K. \& Ward, S., 2002. Virtual Campaigning: Australian Parties and the Impact of the Internet. Australian journal of political science, 37(1), pp.99-129.

Gibson, R., Ward, S. \& Lusoli, W., 2002. The internet and political campaigning: the new medium comes of age? Representations , 39(3), pp.166-180.

Koc-Michalska, K. et al., 2016. The normalization of online campaigning in the web.2.0 era. European journal of disorders of communication: the journal of the College of Speech and Language Therapists, London, 31(3), pp.331-350.

Lassen, D.S. \& Brown, A.R., 2011. Twitter: The Electoral Connection? Social science computer review, 29(4), pp.419-436.

Lilleker, D.G. et al., 2011. Informing, engaging, mobilizing or interacting: Searching for a European model of web campaigning. European Journal of Communication, 26(3), pp.195-213.

Lim, M., 2013a. Many Clicks but Little Sticks: Social Media Activism in Indonesia. Journal of Contemporary Asia, 43(4), pp.636-657. 
Lim, M., 2013b. The Internet and Everyday Life in Indonesia: A New Moral Panic? Journal of the Humanities and Social Sciences of Southeast Asia, 169(1), pp.133147.

Mietzner, M., 2008. Comparing Indonesia's Party Systems of the 1950s and the PostSuharto Era: From Centrifugal to Centripetal Inter-Party Competition. Journal of Southeast Asian Studies, 39(3), pp.431-453.

Naseer, M.M. \& Mahmood, K., 2016. Ready for e-electioneering? Empirical evidence from Pakistani political parties' websites. Internet Research, 26(4), pp.901-918.

Park, H.M. \& Perry, J.L., 2008. Do Campaign Web Sites Really Matter in Electoral Civic Engagement?: Empirical Evidence From the 2004 Post-Election Internet Tracking Survey. Social science computer review, 26(2), pp.190-212.

Porten-Cheé, P., 2013. The Use of Party Web Sites and Effects on Voting: The Case of the European Parliamentary Elections in Germany in 2009. Journal of Information Technology \& Politics, 10(3), pp.310-325.

Prihatini, E.S., 2018. Women's representation in Asian parliaments: a QCA approach. Contemporary Politics, pp.1-23.

Roberts, S.P., 2015. Online Campaigning in Russia: Evidence from the 2011 State Duma Election. Europe-Asia studies, 67(8), pp.1228-1250.

Tapsell, R., 2017b. The political economy of digital media. In E. Jurriens \& E. Jurriens, eds. Digital Indonesia. Singapore: ISEAS-Yusof Ishak Institute Singapore, pp. 5672.

\section{Internet Sources}

Fogg, B.J., 2002. Prominence-interpretation theory: Explaining how people assess credibility, Stanford University, Stanford Persuasive Technology Lab. Available at: http://credibility.stanford.edu/

Johansson, A.C., 2016a. Social Media and Politics in Indonesia. Stockholm School of Economics Asia Working Paper, 42, pp.1-44. Available at: https://swopec.hhs.se/hascer/papers/hascer2016-042.pdf.

Johansson, A.C., 2016b. Tweeting for Power: Social Media and Political Campaigning in Indonesia. Stockholm School of Economics Asia Working Paper, 42. Available at: https://swopec.hhs.se/hascer/papers/hascer2016-043.pdf. 
Keusgen, T., 2016. Indonesia, SE Asia's digital powerhouse. The Jakarta Post. Available at: http://www.thejakartapost.com/academia/2016/08/09/indonesia-seasias-digital-powerhouse.html [Accessed December 12, 2018].

KPU, 2014. Buku Data dan Infografik Pemilu Anggota DPR RI \& DPD RI 2014 [Book of Data and Infographic General Election of DPR RI \& DPD RI 2014], Available at: http://www.kpu.go.id/koleksigambar/Buku Pemilu 2014 Dalam Angka ACC Uplo ad.pdf [Accessed 2016].

Massola, J., 2018. Facebook is the internet for many people in south-east Asia. The Sydney Morning Herald. Available at:

https://www.smh.com.au/world/asia/facebook-is-the-internet-for-many-people-insouth-east-asia-20180322-p4z5nu.html [Accessed December 13, 2018].

Perdana, P.P., 2018. Dekati Generasi Milenial, Airlangga Perbaiki Manajemen Sosmed Golkar [Approaching Millennials, Airlangga Refines Social Media Management at Golkar]. KOMPAS.com. Available at:

https://regional.kompas.com/read/2018/09/18/22515141/dekati-generasi-milenialairlangga-perbaiki-manajemen-sosmed-golkar [Accessed December 3, 2018].

Ramadan, H.R., 2018a. KPU Tetapkan DPT Pemilu 2019 Sebesar 187.781.884 [KPU Sets 2019 Election DPT of 187,781,884]. Komisi Pemilihan Umum. Available at: https://kpu.go.id/index.php/post/read/2018/6551/KPU-Umumkan-Daftar-CalegMantan-Terpidana-Korupsi/berita [Accessed September 27, 2018].

Ramadan, H.R., 2018b. Tim Kampanye, Pelaksana Kampanye, dan Akun Media Sosial Peserta Pemilu Tahun 2019 (Tingkat Pusat) [Campaign Team, Campaign Implementers, and Social Media Accounts for 2019 Election Participants (National Level)]. KPU. Available at: https://kpu.go.id/index.php/pages/detail/2018/958 [Accessed December 9, 2018].

We Are Social, 2018. Digital Report 2018. www.wearesocial.com. Available at: https://digitalreport.wearesocial.com/ [Accessed December 8, 2018]. 
Appendix 1. Parties' Websites and Social Media Accounts (as of 4 December 2018)

\begin{tabular}{|c|c|c|c|c|c|c|c|c|c|c|c|c|c|c|c|c|c|c|c|c|c|c|c|}
\hline$z$ & $\frac{\varpi}{2}$ & 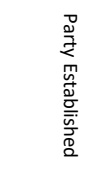 & 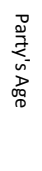 & 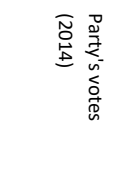 & 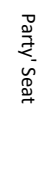 & 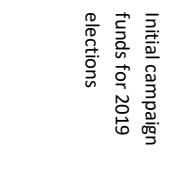 & 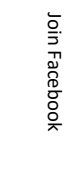 & 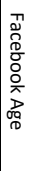 & 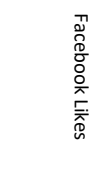 & 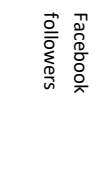 & 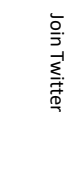 & 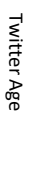 & 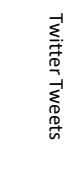 & 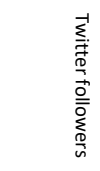 & 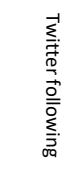 & 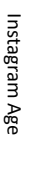 & 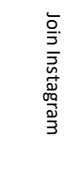 & 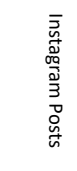 & 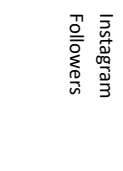 & 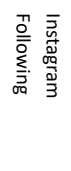 & 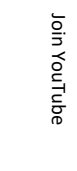 & 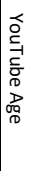 & 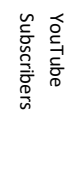 \\
\hline 1 & PKB & 1998 & 20 & 11.292.151 & 47 & 15.235 .981 .000 & 2011 & 7 & 50.735 & 51.254 & 2012 & 6 & 75.400 & 61.200 & 848 & 2 & 2016 & 1.635 & 26.600 & 229 & 2016 & 2 & 532 \\
\hline 2 & Gerindra & 2008 & 10 & 14.750 .043 & 73 & 75.260 .112 .183 & 2011 & 7 & 3.677 .038 & 3.651 .003 & 2011 & 7 & 82.000 & 350.000 & 4.034 & 5 & 2013 & 888 & 332.000 & 346 & 2011 & 7 & 26.750 \\
\hline 3 & PDIP & 1999 & 19 & 23.673 .018 & 109 & 106.143 .479 .741 & 2008 & $\begin{array}{l}1 \\
0\end{array}$ & 1.588 .848 & 1.563 .313 & 2010 & 8 & 45.000 & 178.000 & 1.464 & 5 & 2013 & 816 & 87.400 & 1.157 & 2012 & 6 & 2.381 \\
\hline 4 & Golkar & 1964 & 54 & 18.424 .715 & 91 & 110.000 .000 & 2012 & 6 & 57.132 & 57.206 & 2017 & 1 & 13.200 & 2.745 & 489 & 1 & 2017 & 341 & 9.813 & 407 & 2017 & 1 & 26 \\
\hline 5 & Nasdem & 2011 & 7 & 8.412 .949 & 35 & 5.536 .250 .000 & 2016 & 2 & 8.002 & 8.095 & 2010 & 8 & 50.500 & 70.900 & 788 & 2 & 2016 & 3.631 & 20.000 & 291 & 2017 & 1 & 4.260 \\
\hline 6 & Garuda & 2015 & 3 & & & 1.000 .000 & 2018 & 0 & 1.606 & 1.643 & 2016 & 2 & 0 & 425 & 0 & 2 & 2016 & 41 & 2.891 & 58 & & & \\
\hline 7 & Berkarya & 2016 & 2 & & & 28.636 .420 .000 & 2018 & 0 & 152 & 155 & 2018 & 0 & 44 & 56 & 10 & 0 & 2018 & 153 & 1.844 & 27 & 2016 & 2 & 27 \\
\hline 8 & PKS & 1998 & 20 & 8.455 .614 & 40 & 17.091 .025 .000 & 2011 & 7 & 585.497 & 588.138 & 2009 & 9 & 45.000 & 267.000 & 301 & 5 & 2013 & 2.043 & 141.000 & 122 & 2011 & 7 & 31.742 \\
\hline 9 & $\begin{array}{l}\text { Perindo } \\
\end{array}$ & 2015 & 3 & & & 1.000 .000 & 2013 & 5 & 336.224 & 335.662 & 2013 & 5 & 42.000 & 18.100 & 265 & 3 & 2015 & 8.858 & 169.000 & 165 & & & \\
\hline 10 & $\begin{array}{l}\text { PPP } \\
\text {. }\end{array}$ & 1973 & 45 & 8.152 .957 & 39 & 510.000 .000 & 2017 & 1 & 256.417 & 257.457 & 2010 & 8 & 18.600 & 36.429 & 470 & 3 & 2015 & 1.227 & 104.000 & 52 & 2017 & 1 & 250 \\
\hline 11 & PSI & 2014 & 4 & & & 577.474.910 & 2014 & 4 & 2.685 .511 & 2.689 .634 & 2015 & 3 & 23.600 & 80.000 & 748 & 3 & 2015 & 626 & 106.000 & 125 & 2015 & 3 & 31.936 \\
\hline 12 & PAN & 1998 & 20 & 9.459 .415 & 49 & 50.000 .000 & 2010 & 8 & 184.449 & 183.667 & 2013 & 5 & 17.700 & 39.200 & 239 & 3 & 2015 & 1.535 & 23.900 & 152 & & & \\
\hline 13 & Hanura & 2006 & 12 & 6.575 .391 & 16 & 13.000 .000 & 2017 & 1 & 16.816 & 16.827 & 2017 & 1 & 9 & 23 & 178 & 1 & 2017 & 91 & 518 & 45 & 2017 & 1 & 26 \\
\hline 14 & Demokrat & 2001 & 17 & 12.724 .509 & 61 & 839.400 .000 & 2018 & 0 & 3.500 & 3.558 & 2018 & 0 & 0 & 0 & 2 & 0 & 2018 & 0 & 1 & 0 & & & \\
\hline 19 & PBB & 1998 & 20 & 1.822 .908 & & 16.421 .530 .059 & 2018 & 0 & 5 & 5 & 2018 & 0 & 0 & 0 & 0 & 0 & 2018 & 0 & 12 & 0 & 2018 & 0 & 0 \\
\hline 20 & $\begin{array}{ll}\text { PKPI } \\
\end{array}$ & 1999 & 19 & 1.142 .067 & & 360.000 .000 & & & & & & & & & & & & & & & & & \\
\hline
\end{tabular}




\section{Appendix 2. Party website scoring sheets}

\begin{tabular}{|c|c|c|c|c|c|c|}
\hline $\begin{array}{l}\text { party's } \\
\text { number }\end{array}$ & Political Party & website address & $\begin{array}{l}\text { information } \\
\text { provision (0- } \\
16)\end{array}$ & $\begin{array}{l}\text { mobilization } \\
(0-19)\end{array}$ & $\begin{array}{l}\text { Engagement } \\
\qquad(0-n)\end{array}$ & $\begin{array}{l}\text { technical sophistication } \\
\qquad(0-14)\end{array}$ \\
\hline 1 & Partai Kebangkitan Bangsa (PKB) & www.pkb.id & 9 & 3 & 3 & 5 \\
\hline 2 & Partai Gerakan Indonesia Raya (Gerindra) & www.partaigerindra.or.id & 8 & 6 & 3 & 4 \\
\hline 3 & $\begin{array}{l}\text { Partai Demokrasi Indonesia Perjuangan } \\
\text { (PDIP) }\end{array}$ & www.pdiperjuangan.id & 9 & 6 & 4 & 7 \\
\hline 4 & Partai Golongan Karya (Partai Golkar) & www.partaigolkar.or.id & 14 & 7 & 54 & 7 \\
\hline 5 & Partai Nasdem & www.partainasdem.id & 7 & 3 & 1 & 3 \\
\hline 6 & $\begin{array}{l}\text { Partai Gerakan Perubahan Indonesia } \\
\text { (Garuda) }\end{array}$ & partaigaruda.org & 3 & 3 & 3 & 5 \\
\hline 7 & Partai Berkarya & www.berkarya.id & 10 & 9 & 5 & 7 \\
\hline 8 & Partai Keadilan Sejahtera (PKS) & www.pks.id & 10 & 11 & 113 & 7 \\
\hline 9 & Partai Persatuan Indonesia (Perindo) & www.partaiperindo.com & 5 & 5 & 72 & 6 \\
\hline 10 & Partai Persatuan Pembangunan (PPP) & www.ppp.or.id & 4 & 6 & 3 & 4 \\
\hline 11 & Partai Solidaritas Indonesia (PSI) & www.psi.id & 11 & 16 & 1 & 8 \\
\hline 12 & Partai Amanat Nasional (PAN) & www.pan.or.id & 8 & 4 & 6 & 4 \\
\hline 14 & Partai Demokrat & www.demokrat.or.id & 8 & 4 & 2 & 5 \\
\hline \multirow[t]{2}{*}{19} & Partai Bulan Bintang (PBB) & www.partaibulanbintang.or.id & 7 & 4 & 2 & 3 \\
\hline & & Mean & 8.071428571 & 6.214285714 & 19.42857143 & 5.357142857 \\
\hline
\end{tabular}

